${ }^{3}$ Plamenac P, Nikulin A, Pikula B. Cytology of the respiratory tract in former smokers. Acta Cytol 1972;16:256-60.

- Schreiber H, Bibbo M, Wied GL, Saccomanno G, Nettesheim P. Bronchial metaplasia as a benign or premalignant lesion. 1. Cytologic and ultrastructural discrimination between acute carcinogen effects and toxin-induced changes. Acta Cytol $1979 ; 23: 496-503$.

; Tipton DL, Crocker TT. Duration of bronchial squamous metaplasia produced in dogs by cigarette smoke condensate. Fournal of the National Cancer Institute 1964;33:487-95.

${ }^{6}$ Baskerville A. The development and persistence of bronchial gland hyper- trophy and goblet cell hyperplasia in the pig after injection of isoprenaline. $\mathcal{f}$ Pathol 1976;119:35-47.

7 Bertram JF, Rogers AW. The development of squamous cell metaplasia in human bronchial epithelium by light microscopic morphometry. $\mathfrak{f}$ Microsc $1981 ; \mathbf{1 2 3}: 61-73$.

${ }^{8}$ US Department of Health, Education and Welfare. Smoking and health: a report of the surgeon general. Washington: US Department of Health, Education and Welfare, 1979.

(Accepted 15 September 1981)

\title{
Role of mucosal injury in initiating recurrent aphthous stomatitis
}

\author{
DAVID WRAY, EDWARD A GRAYKOWSKI, ABNER LOUIS NOTKINS
}

\begin{abstract}
The buccal mucosa of 30 patients with recurrent aphthous stomatitis and $\mathbf{1 5}$ healthy controls was injured by suture and penetration with a tenaculum and a hypodermic needle and each of the six puncture wounds produced monitored for up to seven days for the development of ulcers.

Altogether 26 lesions were induced in 13 patients, whereas none occurred in the controls $(p<0.001)$. Sutures caused most of the lesions (15), and those so induced had a mean maximum diameter of $2.3 \mathrm{~mm}$ and lasted for an average of four days. Ulcers induced mechanically were clinically indistinguishable from those usually seen in the patients, except that they were generally smaller and healed more quickly.

These findings confirm that mechanically induced injury of the oral mucosa may cause ulceration in people susceptible to aphthous stomatitis. Such a procedure may therefore be helpful in identifying subsets of patients.
\end{abstract}

\section{Introduction}

Recurrent aphthous stomatitis is the most common disease of oral mucous membranes. ${ }^{1}$ It is characterised by painful ulcers occurring singly or in crops. These ulcers typically last from seven to 14 days. Individual recurrences may be continuous or separated by varying periods of remission. The aetiology of the disease is not known but appears to be multifactorial.

This study was initiated to determine whether standardised mechanical injury would lead to ulcers in patients prone to aphthous stomatitis when compared with normal controls.

\section{Subjects and methods}

We studied 30 patients with recurrent aphthous stomatitis. Their ages ranged from 21 to 60 years (mean 36), and they had suffered from ulcerations for five to 55 years (mean 22.9 years). Nineteen

\footnotetext{
Laboratory of Oral Medicine, National Institute of Dental Research, National Institutes of Health, Bethesda, Maryland 20205

DAVID WRAY, MB, FDS, visiting associate

EDWARD A GRAYKOWSKI, MD, DDS, research scientist

ABNER LOUIS NOTKINS, MD, laboratory chief
}

were women (mean age 35.9 years) and 11 men (mean age 36.1 years) Twenty-eight patients clinically had recurrent aphthous stomatitis of the minor type, one had major aphthae, and one had herpetiform ulcers." Fifteen healthy volunteers without recurrent aphthous stomatitis and matched for age and sex served as controls.

The buccal mucosa was injured by three different methods. Firstly, local anaesthesia of the long buccal nerve was induced by injecting $0.5 \mathrm{ml} \mathrm{3 \%}$ mepivacaine without vasoconstrictor into the tissues overlying the junction of the ascending ramus and the body of the mandible. A further $0.5 \mathrm{ml}$ was injected submucosally into the buccal sulcus opposite the first mandibular molar. Each injection site served as a hypodermic needle wound. Secondly, once anaesthesia was established a $3 / 0$ black silk suture was inserted into the buccal mucosa below the linea alba, creating an entry and exit wound. This suture remained in situ for 24 hours before removal. Thirdly, a towe tenaculum was used to pierce the mucosa at a site $2 \mathrm{~cm}$ from the suture wound and removed immediately, leaving two sites of penetration of the oral mucosa. Each method therefore produced two puncture wounds. Only one side of the mouth was used, which was assigned at random. The procedure was carried out only when the area was free of spontaneous ulcers.

All patients and controls were seen on the first, third, fifth, and seventh days after the procedure, and lesions were measured and assessed. In addition, the subjects kept a daily record of the size, appearance, and degree of pain at the injured site. The size of the ulcers was recorded as maximum diameter $(\mathrm{mm})$. The patients scored the pain subjectively as 0 , painless; 1 , slight discomfort; 2 , moderate pain; and 3 , severe pain. If lesions persisted for more than seven days the patient was seen at three-day intervals until healing occurred.

\section{Results}

Of the 30 patients tested, 13 developed lesions at one or more of the puncture sites; none of the 15 controls developed ulcers (see table). This difference was significant $\left(\chi^{2}\right.$ test: $\left.p<0.001\right)$. Subject 1 developed ulcers at five of the six puncture sites: two at the site of the suture wound, two where the tenaculum had been placed, and one at the needle wound. Subjects 2 and 3 developed aphthous lesions at both the suture and tenaculum sites, and subject 4 developed lesions at both the suture and needle-puncture sites. Nine patients developed lesions in response to only one type of injury, but in four cases two lesions developed. In all, 13 patients developed 26 ulcers. Seventeen of the 30 patients failed to develop lesions, and in these and the controls the initial puncture wound did not progress, was associated with minimal erythema, and disappeared within 24 hours.

Sutures caused the most lesions. Thus 15 ulcers with a mean maximum diameter of $2.3 \mathrm{~mm}$ (range $1.0-3.0 \mathrm{~mm}$ ) were induced in this way. These ulcers lasted for an average of four days (range two to seven days) and were associated with a varying degree of pain (mean pain score 1.4 ; range $0-3$ ). Nine ulcers occurred at the tenaculum site with a mean diameter of $1.4 \mathrm{~mm}$ (range $1.0-5.0 \mathrm{~mm}$ ) and lasted 
Number, site, size, duration, and pain score of aphthous lesions induced in 30 patients with recurrent aphthous stomatitis and 15 controls by mechanical injury

\begin{tabular}{|c|c|c|c|c|c|c|c|c|c|c|}
\hline \multirow{3}{*}{ Subjects } & \multicolumn{9}{|c|}{ Method of inducing injury } & \multirow{3}{*}{$\begin{array}{l}\text { Total } \\
\text { ulcers }\end{array}$} \\
\hline & \multicolumn{3}{|c|}{ Suture } & \multicolumn{3}{|c|}{ Tenaculum } & \multicolumn{3}{|c|}{ Needle } & \\
\hline & $\begin{array}{l}\text { Size } \\
(\mathrm{mm})\end{array}$ & $\begin{array}{c}\text { Duration } \\
\text { (days) }\end{array}$ & $\underset{\text { (score) }}{\text { Pain }}$ & $\begin{array}{c}\text { Size } \\
(\mathrm{mm})\end{array}$ & $\begin{array}{c}\text { Duration } \\
\text { (days) }\end{array}$ & $\begin{array}{c}\text { Pain } \\
\text { (score) }\end{array}$ & $\begin{array}{c}\text { Size } \\
(\mathrm{mm})\end{array}$ & $\begin{array}{c}\text { Duration } \\
\text { (days) }\end{array}$ & $\underset{\text { (score) }}{\text { Pain }}$ & \\
\hline \multicolumn{11}{|c|}{ Aphthous group* } \\
\hline 1 & $\left\{\begin{array}{l}2 \\
2\end{array}\right.$ & $\begin{array}{l}4 \\
4\end{array}$ & $\begin{array}{l}2 \\
2\end{array}$ & $\begin{array}{l}2 \\
3\end{array}$ & $\begin{array}{l}10 \\
14\end{array}$ & $\begin{array}{l}1 \\
2\end{array}$ & 1 & 3 & $0\}$ & 5 \\
\hline 2 & $\left\{\begin{array}{l}2 \\
5\end{array}\right.$ & $\begin{array}{l}4 \\
4\end{array}$ & $\begin{array}{l}3 \\
3\end{array}$ & 0.5 & 3 & 2 & & & & 3 \\
\hline 3 & $\left\{\begin{array}{l}1 \\
1\end{array}\right.$ & $\begin{array}{l}2 \\
2\end{array}$ & $\begin{array}{l}0 \\
0\end{array}$ & 1 & 2 & 0 & & & & 3 \\
\hline 4 & 2 & 7 & 2 & & & & 1 & 3 & 0 & 2 \\
\hline 5 & $\left\{\begin{array}{l}2 \\
2\end{array}\right.$ & $\begin{array}{l}3 \\
4\end{array}$ & $\begin{array}{l}0 \\
0\end{array}$ & & & & & & \} & 2 \\
\hline 6 & $\left\{\begin{array}{l}3 \\
3\end{array}\right.$ & $\begin{array}{l}4 \\
5\end{array}$ & $\begin{array}{l}1 \\
1\end{array}$ & & & & & & \} & 2 \\
\hline 7 & $\left\{\begin{array}{l}2 \\
2\end{array}\right.$ & $\begin{array}{l}4 \\
4\end{array}$ & $\begin{array}{l}3 \\
3\end{array}$ & & & & & & \} & 2 \\
\hline 8 & & & & $\left\{\begin{array}{l}0.5 \\
1\end{array}\right.$ & $\begin{array}{l}3 \\
4\end{array}$ & $\begin{array}{l}0 \\
0\end{array}$ & & & \} & 2 \\
\hline $\begin{array}{c}9 \\
10 \\
11 \\
12 \\
13 \\
14-30\end{array}$ & $\begin{array}{l}3 \\
2\end{array}$ & $\begin{array}{l}3 \\
7\end{array}$ & $\begin{array}{l}1 \\
0\end{array}$ & $\begin{array}{l}2 \\
1 \\
1.5\end{array}$ & $\begin{array}{l}3 \\
3 \\
4\end{array}$ & $\begin{array}{l}1 \\
2 \\
1\end{array}$ & & & & $\begin{array}{l}1 \\
1 \\
1 \\
1 \\
1 \\
0\end{array}$ \\
\hline \multicolumn{11}{|c|}{ Control group } \\
\hline $31-45$ & & & & & & & & & & 0 \\
\hline
\end{tabular}

*Order of patients altered for tabulation. Subject 4 usually had herpetiform ulcers. Subject 10 usually had major aphthae.

for an average of five days (range two to 14 days). They were less painful than the ulcers associated with the suture wound, having a mean pain score of 1.0 (range $0-2$ ). Only two lesions developed at the injection sites; they did not exceed $1 \mathrm{~mm}$ diameter and were painless.

\section{Discussion}

Clinicians have long suspected that trauma may initiate lesions in patients with a history of recurrent aphthous stomatitis. $^{3-5}$ Our studies support this. The mechanically induced ulcers were clinically indistinguishable from the spontaneous ulcers usually seen in the patients, except that the lesions were generally smaller and healed more quickly. In our experiments and others ${ }^{6}$ biopsies failed to disclose any histological differences between mechanically induced and spontaneous ulcers. Moreover, there was no clinical difference between the group of patients who ulcerated and those who did not.

The phenomenon of lesions being induced by injury is also observed in Behçet's syndrome, where intradermal injection causes formation of pustules and mucosal injury initiates mouth ulcers. ${ }^{6}$ Moreover, in Behçet's syndrome mast cells are present in increased numbers at the site of mechanical injury. ${ }^{7}$ Patients with Behçet's syndrome also show an increased sensitivity to inflammatory mediators, such as histamine, which induce skin pustules when inoculated intradermally. ${ }^{8}$ In Ehlers-Danlos syndrome the oral tissue is also more sensitive to injury, ${ }^{9}$ presumably owing to defective synthesis of collagen. ${ }^{10}$ We do not know whether the greater sensitivity of the mucosa to mechanical injury in patients with recurrent aphthous stomatitis is due to impaired wound repair, more rapid mobilisation of mast cells, the detrimental effects of histamine release, or other factors. Regardless of mechanism, our experiments suggest that mechanical injury may aid in identifying and studying subsets of patients who are prone to aphthous stomatitis.

\section{References}

1 Lehner T. Autoimmunity in oral diseases, with special reference to recurrent oral ulceration. Proc $R$ Soc Med 1968;61:515-24.

${ }^{2}$ Hooks JJ, BenEzra D, Cohen L, et al. Classification, pathogenesis and etiology of recurrent oral ulcerative diseases and Behçet's syndrome. f Oral Pathol 1978;7:436-8.

${ }^{3}$ Ross R, Kutscher AH, Zegarelli EV, Silvers H, Piro JD. Relationship of mechanical trauma to recurrent ulcerative (aphthous) stomatitis. NY State Dent $\mathcal{F} 1958 ; 24: 101-2$.

+ Spouge JD, Diamond HF. Hypersensitivity reactions in mucous membranes. I. The statistical relationship between hypersensitivity diseases and recurrent oral ulcerations. Oral Surg 1963;16:412-21.

${ }^{5}$ Graykowski EA, Barile MF, Lee WB, Stanley HR. Recurrent aphthous stomatitis. Clinical, therapeutic, histopathologic and hypersensitivity aspects. F $A M A 1966 ; 196: 637-44$.

6 Nazzaro P. Cutaneous manifestations of Behçet's disease. In : Monacelli M, Nazzaro P, eds. Behfet's disease. Basle: Karger, 1966:15-41.

7 Haim S, Sobel JD, Friedman-Birnbaum R, Lichtig C. Histological and direct immunofluorescence study of cutaneous hyperreactivity in Behçet's disease. Br $\mathcal{F}$ Dermatol 1976;95:631-6.

${ }^{8}$ Matsomura N, Matsomura Y, Mizushima Y. Studies on cutaneous hyperreactivity and leukocyte chemotaxis in Behçet's disease. In: Dilsen N, Konice M, Ovul C, eds. Behçet's disease. Proceedings of an international symposium on Behçet's disease. Amsterdam-Oxford: Excerpta Medica, 1979:219-23.

${ }^{9}$ Pindborg JJ. Diseases of the skin. In: Jones JH, Mason DK, eds. Oral manifestations of systemic disease. London: Saunders, 1980:365.

${ }^{10}$ Bornstein P, Byers PH. Current concepts: collagen metabolism. Michigan: Upjohn, 1980:21-38.

(Accepted 22 September 1981)

IF deafnefs proceeds from drynefs of the ears, which may be known by looking into them, half an ounce of the oil of fweet almonds, and the fame quantity of liquid apodeldoch, or tincture of afafœetida, may be mixed together, and a few drops of it put into the ear every night at bed-time, ftopping them afterwards with a little wool or cotton. Some, inftead of oil, put a fmall flice of the fat of bacon into each ear, which is faid to anfwer the purpofe very well. When the ears abound with moifture, it may be drained off by an iflue or feton, which fhould be made as near the affected parts as poffible.

SOME, for the cure of deafnefs, recommend the gall of an eel mixed with fpirit of wine, to be dropped into the ear; others, equal parts of Hungary-water and fpirit of lavender. Etmuller extols amber and mufk; and Brookes fays, he has often known hardnefs of hearing cured by putting a grain or two of mulk into the ear with cotton-wool. But thefe and other applications muft be varied according to the caufe of the diforder.

(Buchan's Domestic Medicine, 1786.) 